\title{
The Influence of Question and Answer Methods On The Development of Critical Thinking In Early Children
}

\author{
Yolandha Asika Putri ${ }^{1}$ \\ ${ }^{1}$ Muhammadiyah Surakarta university \\ Dr. Choiriyah Widyasari, S.Psi., M.Psi. ${ }^{2}$ \\ ${ }^{1}$ Muhammadiyah Surakarta university
}

\begin{abstract}
Question and answer method is one method that can improve various abilities and can optimize various developments needed by children in a way that is fun and interesting for children. Critical thinking facilitates children to explore and find out the knowledge around them so that they can add insight to children. The purpose of this research is to examineliterature,journals, articles, and documents from research results that highlight the influence of question and answer methods on the development of critical thinking in early childhood. The reference journal used is in the form of premiere articles of approximately 20 journals, which are divided into 15 national journals with a period of the last 5 years, and 5 international journals with a period of the last 7 years.Literature,journals, articles, and documents used are of high quality, accredited, and reputable. The sample is a research journal on the topic of question and answer (discussion) / critical thinking skills of early childhood. With the criteria selected journal is1) question and answer method; 2) early childhood critical thinking; 3) respondents are early childhood; 4) research results published in the 2015-2020 timeframe. The literature review shows that children's critical thinking skills can solve the problems they face such as in puzzle games, the concept of time, color mixing experiments, as well as analyzing and summarizing the knowledge gained. Likewise with the question and answer method, a method that can foster a variety of developments needed by early childhood, such as communication skills and language skills through a variety of games that are interesting and fun for children, such as telling stories, learning to use flip charts, composing puzzles, and also use the play method.
\end{abstract}

KEY WORDS

question and answer method, think critically, early childhood
ECRJ (Early Chilhood Research Journal) ISSN Numbers: Print, 2655-6448; Online, 2655-9315

\section{CORRESPONDING AUTHOR:}

email:yolandhaasika75@gmail.com

Manuscript submitted October 10, 2020; accepted December 27, 2020.

Copyright: (C2019 This is an open access article under the terms of the Creative Commons Attribution License, which permits unrestricted use, distribution, and reproduction in any medium, provided the original author and source are credited.

\section{INTRODUCTION}

Muhibbin Syah, (2010) states that education is formed from the word "educate", then gets the prefix "me" then becomes

\section{ADDRESS}

Website: http://journals.ums.ac.id/index.php/ecrj Address: Pendidikan Guru PAUD

Universitas Muhammadiyah Surakarta

A. Yani Street No. 1, Pabelan, Kartasura, Surakarta, Indonesia Telp. +62-271-717417 ext.

Email: ecrj@ums.ac.id

"educating" which means, fostering and providing guidance. In developing and providing guidance, teachings, instructions, and direction are needed regarding morals and intelligence. 
Through the provision of guidance, teaching and educational guidance, planning is also needed that can create an active learning atmosphere. Such as education according to the SISDIKNAS Law no. 20 (2003) which explains that education isways to get up and plan to maintain an atmosphere of learning and active learning activities and also to foster children's potential to get the concept of religion, social emotional, character, intelligence, good morals, as well as skills needed by children and the community.

According to Indrijati (2017) Education is also very important starting from an early age or from infancy, here the obligations of parents and immediate family are very important in educating children. Starting from the foundation of the child requires a good environment and helps him to be a child who is superior and has optimal development.

Education that children have received in the family environment can be optimized by including children in preschool education, where in preschool education children can develop more optimally and be stimulated according to their developmental needs, in Indonesia itself early childhood is usually included in schools called Children's Education Early age, which can be abbreviated as PAUD. The definition of PAUD in Indonesia is explicitly and juridically described in Law no. 20 (2003) which discusses the national education system. In article 01, point 14,

PAUD basically explains that the education that is carried out aims to facilitate the overall development of the child and also focuses on the development of all aspects of the characteristics of the child. Therefore,
PAUD opens opportunities for children to develop their characteristics and potentials optimally.

According to Mansur (2009) PAUD is very important for children, so the purpose of education is not only to be able to go to school formally and gain knowledge, but the benefits that will be obtained will be more than that. Development of children will develop optimally and perfectly (comprehensive) so that someday they can become human beings who are beneficial to the surrounding environment, nation, and religion.

Children who get optimal education are in the healthy category, which is emotionally healthy, characteristic, socially emotional, religious and also physically healthy. Education in children is very good starting from birth, starting from parents, schools and the surrounding environment. In education it is also important to include three aspects, namely cognitive, affective, and psychomotor and also to prepare children for the next education level.

According to Suyadi and Ulfah (2013) said that in order to get maturity to face higher education, it can also be described in general, namely by stimulation and stimulation for growth and development and potential of children so as to form humans who obey God Almighty, have noble character, manners. , physically and mentally healthy, and also responsible.

Early childhood education requires learning methods that can be applied in teaching and learning activities, described by JR David as quoted by Sudaryono (2016) as saying "a way in achieving something" which 
means "a way to achieve something". To implement and apply these methods in learning, a certain set of methods is used which aims to achieve optimal learning.

The method according to Sudaryono (2016) is how to make the concepts that have been made can be applied clearly in daily activities and the desired objectives are achieved optimally. In other words, the method that has been applied can be implemented in accordance with the predetermined strategy. So that the method in the learning arrangement is an important role. The method used in learning by the teacher can be created as attractive as possible in the child's learning environment so that the interaction between the teacher and the child can take place actively and optimally. One of them is using the learning method, which can make the learning atmosphere of children and teachers active and diverse.

So that the method in the arrangement of teaching and learning activities becomes an important role. Success in implementing strategies in teaching and learning activities is an important point for how teachers apply learning methods because using strategies in learning can make learning organized and planned.

So using the method in learning can play an important role for teachers and children, the question and answer method is also very important to provide activity for teachers and children because this question and answer method is a two-way communication.

Sukadinata (2011) states that the question and answer method is learning that makes direct communication and two-way communication, but at the same time there are conversational activities carried out by children and teachers, children ask and answer or vice versa the teacher asks and answers. Then the conversation that occurs becomes a direct communication that occurs by the child and the teacher.

In the teaching-learning process according to Sukadinata (2011), asking questions is an important role for children because well-structured sentences also use the correct technique so that it can expand children's learning activities as well as increase children's interest and curiosity through problems that become topic of conversation is also the issue being discussed. Expanding the child's thinking pattern, learning actively, and guiding the child's thinking process through the right questions will enable the child to be able to find answers correctly and correctly, so that the child is able to concentrate on problems that are currently being discussed, giving children the opportunity to ask questions that have not understood.

Using this question and answer method can also hone critical thinking in children. According to Zakiyah and Lestari (2019) critical thinking is a process of reflective thinking which focuses on deciding also to believe or what to do. Ratna et al (2017) also say that someone can be said to be able to think critically so that someone can think logically, reflectively, systematically, and is also accurate when making calculations and making decisions appropriately.

There isseveral aspects of critical thinking according to Zakiyah and Lestari 
(2019), such as interpretation, analysis and explanation. In brief, these three aspects explain the ability to know the purpose of identifying an experience and the ability to state the results of the experience gained.

Due to the increasing advancement of education in Indonesia, a structured arrangement is needed and most importantly in AUD education. So the implementation of learning in PAUD makes teachers have to carry out various ways and also always take an active role to stimulate and answer to children, seeing that many children still experience difficulties caused by lack of knowledge as well as lack of critical thinking skills in children.

With the role of stimulating teachers as well as honing children's critical thinking skills can influence and improve children's critical thinking skills, which in today's world is very much needed how children can decide what to believe and will do.

In view of the above, that the teacher plays an important role in the development of children's critical thinking through the question and answer method and also provides stimulations for children. So the application of the question and answer method in early childhood education and improving critical thinking in children is very important for the development of their thinking, which will be needed later in higher education levels and also useful in the environment around children such as parents, families, and communities.

It is hoped that the application of the question and answer method can develop critical thinking in children. The teacher can ask the child, and the child responds well, making the child also happy to ask the teacher about the experiences they have had, and asking new things that the child gets by answering these questions and sharpening their critical thinking. So the development of critical thinking in children can also develop effectively and increase knowledge and insight for children.

So the researchers decided to raise the title "Question and Answer Methods for the Development of Critical Thinking in Early Childhood".

\section{RESEARCH METHOD}

This research is a secondary research in the form of a literature review in other words, an analysis which is a criticism (building or dropping) through research that has been carried out on a special topic as well as a problem from a particular section of science (Agusta, 2008). Literature analysis can also be found through various sources including journals, books, documentation, internet and literature. The method of literature analysis is a series of activities that work together with the methods of collecting library data, reading, and taking notes, and managing writing materials (Sugiyono, 2016). The type of writing used is literature review analysis, which focuses on the results of writing related to the topic or variable being written.

This study uses data that has been carried out and published by online, national and international journals. In carrying out this research, the researchers conducted a search for research journals that have been published on the internet using the Research Gate, 
National Library, and Schoolar seach engine with the keywords critical thinking skills and question and answer method.

So in this study, researchers analyzed the effect of the question and answer method on the development of critical thinking in early childhood. The independent variable is the influence of the question and answer method, the dependent variable is the development of early childhood critical thinking. For the population that is all journals from the results of research on the topic of questions and answers (discussion) / critical thinking of early childhood. The sample is a research journal with the topic of question and answer method (discussion) / early childhood critical thinking according to the criteria of the selected journal, namely: 1) question and answer method; 2) early childhood critical thinking; 3 ) respondents are early childhood; 4) research results published in the 2015-2020 timeframe. References in the form of premiere articles of approximately 20 articles and 15 national journals with a period of the last 5 years, and 5 international journals with a period of 7 years. The journal review flow in this literature review is carried out in accordance with Figure 1.

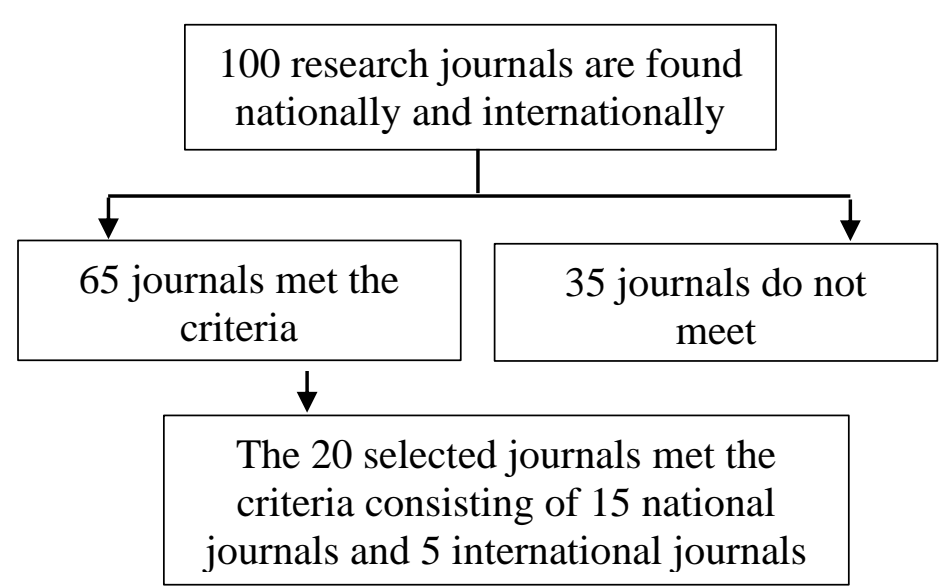

Literature review begins with material from the writing that according to the sequence is observed from very relevant, relevant, to quite relevant. Then first read the abstract, in each journal to be able to give an assessment of whether the problem being studied is appropriate or not with what will be sorted in a journal. Write important points and their relevance according to the research problem, so as not to be included in the plagiarism element. The author should note the source of the information as well as write a bibliography. If true, the information is the result of other people's thoughts or writings. prepare notes, quotes, or information neatly arranged so that the author can easily search again if at any time needed (Darmadi, 2011 in Nursalam, 2016).

Journals that are in accordance with the criteria can then be put together and a journal summary is made according to the title, name of the researcher, year of publication, type and design of the study, population, sample, variables, techniques and instruments, data analysis and research results. Then the selected journal summary is then written into a table and sorted in accordance with the format above.

For to explain abstract analysis and journal completely, it must be read and understood. The journal summary will then be analyzed according to the contents of the research objectives and research findings. The method used uses journal content analysis. 
RESULTS AND DISCUSSION

Increase Art Appreciation in Children and Critical Thinking Based on Visual Literacy Program Interventions (Kyoung Jin Kim, et al, 2017)

The results of this study resulted in an increase in developing children's appreciation and also critical thinking in children, from the artwork that the children made them to tell interesting background stories. By telling the background of the artwork made, namely painting, children can provide reasons, comparing the work of art.

Building Children's Critical Thinking by Telling Puzzle Stories (Elise Muryanti, et al, 2016)

The results of the research at the first meeting were that of the 20 children who attended grade $16(80 \%)$ of whom were able to do their own picture arrangements and short stories based on picture settings, at the second meeting there was an increase of $(86.6 \%)$ at this second meeting the children could tell stories with good and think critically in developing a story.

\section{Critical Thinking Skills Test for Children}

Ages 5-6 Years (CTTC) (Kevser Tozduman Yarah, et al, 2020)

By using this critical thinking skill test, it can be seen that the test used is very accurate and valid, because critical thinking does not appear automatically in adulthood but is developed and matured at an early age, and this CTTC makes it possible to evaluate critical thinking in children.

The Effectiveness of Philosophy with the Children's Curriculum on PreSchool Children's Critical Thinking Skills (Filiz Karadag, et al, 2018)

The results of the research were that there was a positive impact on critical thinking, language skills and children's cognitive.

Developing Early Childhood Ability in Understanding Rules Using a Combination of Role Playing Models and Question and Answer Methods through Traffic Signs (Novitawati, et al, 2018) The results of the research conducted by the researcher, namely the implementation of learning using traffic signs in group B went well and achieved very good criteria.

Character Value, Critical Thinking, and Early Childhood Psychomotor (Syarip Hidayat, et al, 2018)

The results of the research from the TK Nurul IImi data were critical thinking with a presentation of $49.80 \%$, psychomotor with a percentage of $50.87 \%$, while the character value with a percentage of $50.06 \%$, with this the highest score acquisition in TK Nurul IImi was psychomotor with a percentage of $50.87 . \%$. The results of the research at TK Nergeri Pembina are critical thinking with a presentation of $50.98 \%$, psychomotor with percentage acquisition of $52.17 \%$, while the percentage of character values obtained 
is $51.22 \%$. The highest score in the TK Negeri Pembina is Psychomotor with a presentation of $52.17 \%$.

Improving Critical Thinking Ability through Scientific Approach (Herina Yuniati, et al, 2019)

The results of the study found the progress of critical thinking skills in children through a scientific approach. The ability to think critically is seen when children are able to observe concrete objects used in activities.

Improving Critical Thinking Ability through Environmental-Based Experimental Methods (Cheristy Anggreani, 2015)

The results of this study were an increase in the percentage of $40.27 \%$ in the first cyle increased to a percentage of $56.03 \%$ and then in the second cycle increased to $88.48 \%$.

$\begin{array}{lrrr}\text { Improving } & \text { Critical } & \text { Thinking } & \text { Skills } \\ \text { through } & \text { Playing } & \text { Science in }\end{array}$
Kindergarten Children at Paud Yasmin's Laboratory (Misyana, et al, 2019)

The result of this research is that in cycle 1 the percentage obtained is $60 \%$, cycle 2 increases the presentation to $86.66 \%$. So there is an increase in each cycle.

Critical Thinking Construction Through Introduction to Clock Functions and the Concept of Time in Early Childhood (Wahyu Dyah Laksmi Wardhani, et al, 2018)

The results of this study were successfully carried out and can improve critical thinking in children, where the research was carried out in stages in introducing the clock function in a comprehensive manner. Where the concept of time is an abstract concept that can help children improve critical thinking.

The Effect of Learning Models and Critical Thinking Ability on Understanding Physical Science (Ayu Citra Dewi, et al, 2019)

The results of the study were that the first children with an understanding of learning using quantum had more influence in increasing critical thinking compared to using contextual teaching and learning. Second, there is an influence on the high and low ability of critical thinking in the interaction of the learning model. The third critical thinking ability of children in quantum model learning has a higher score than the contextual teaching and learning learning model. The conclusion is the Learning Model and the Critical Thinking Ability to Understanding Physical Science in Group B Kindergarten in Kenagarian Peninjau and Tanjung Sani Kec. Tanjung Raya, Kab. Religion is increasing.

Improvement of Critical Thinking Ability in Learning Science through the B1 Group Play Method at Kindergarten Aisyiyah Punggawan 2016/2017 (Nur Fadlila, et al, 2019)

The results of the research are the percentage of precedents obtained that is $38.09 \%$ or as many as 8 children, the first cycle has increased ie the percentage obtained is $61.90 \%$ or 13 
children, the second cycle gets a percentage of $85.71 \%$ or 18 children, which means the method play can improve children's critical thinking.

Efforts To Improve The Ability To Speak Through Question and Answer Method in Children aged 4-5 years (Acih Munasih,et al, 2017)

The results of the research on the results of cycle 1 were $68 \%$, in the second cycle the percentage increased to $80 \%$, in the third cycle it increased to $95 \%$. Based on the percentage of diats, the question and answer method can improve speaking skills.

Developing Early Childhood Ability to Understand Noble Behavior (Honest, Helper) Using a Combination of Storytelling Methods, Question and Answer Methods, and Examples Non Examples Methods (Oktafiola Maharani Putri, et al, 2017)

The results of the research on the observation sheet at the 3rd meeting experienced an increase compared to the first meeting with quite good criteria, then at the second meeting with good criteria, and at the 3rd meeting with very good criteria. Therefore, efforts to develop children's abilities have increased very well.

The Influence of Question and Answer Methods on Early Childhood Learning Motivation in Kanzul Makarim Kindergarten Glenmore Banyuwangi (Firman Ashadi, 2018)The results of the study entitled The Influence of Question and Answer Methods on Early
Childhood Learning Motivation, namely the effect on children's learning motivation in Kindergarten Kanzul Makarim. Improvement of Vocal Letters Recognition Language Ability Through Question and Answer Methods in Children in Playgroups (Eka Kusuma Wardhani, et al, 2015)The results of the research in cycle 1 were $64 \%$, cycle 2 increased to $78.5 \%$, there was an increase in the ability to recognize vowels through the question and answer method by $78.5 \%$ and it can be concluded that this study was successful.

The effect of puzzle games and discussion methods on knowledge and attitudes of early childhood (5-6 years) regarding sexuality (study at Kindergarten, Bugangan, East Semarang, Semarang City (Hasna Fadhilah Muflihah, et al, 2019)

The knowledge that early childhood children get about sexuality increases by $40 \%$ after intervening learning and playing through puzzels using the discussion method with group friends.

Improving Language Development through Question and Answer Methods assisted by Flip Chart Media in B1 Kindergarten Children Ikal Widya Kumara (Marsye Ruth Hendria Pasanea, et al, 2015)So that the results can be concluded that the question and answer method used in this study can be improved.

Improving Children's Ability to Communicate Through Question and 
http://journals.ums.ac.id/index.php/ecrj

Answer Methods in Group B Kindergarten Andine Palupi (Herawati, et al, 2019)

The first cycle in the cycle pointing letters in sequence shows a presentation of $15.00 \%$ to $20.00 \%$, in the category pointing to letters randomly getting a presentation of $15.00 \%$, arranging words gets a presentation of $10.00 \%$ to $15.00 \%$. In the second cycle the category shows the letters sequentially increase in presentation to $50.00 \%$, randomly assign letters to the percentage of $55.00 \%$, and according to the wording, the increase also becomes $55.00 \%$. So
The Influence of Question...

that the conclusion fromlmproving Children's Ability to Communicate Through Question and Answer Methods in Group B Kindergarten Andine Palupi improved.

Improve Language Ability of 5-6 Years Old Children by Applying Question and Answer Methods (Afriliyanti Muslimah, et al, 2018)

In the first cycle has increased but the criteria are sufficient. In the first cycle got a presentation of $43.48 \%$ and in the second cycle to $78 \%$. So the conclusion obtained is to improve language skills of children aged 5-6. 


\section{DISCUSSION}

All articles that are the sample of this research are the results of research from classroom action, experimentation, quantitative, qualitative and descriptive. There are nine using classroom action research, three using experimental research, three using quantitative research, three using qualitative research, two using descriptive research.

The population used in the twenty journals is children with susceptibility aged 3-6 years. The number of resource persons included in each study ranged from 10-202 children.

\section{Critical thinking}

The number of journals selected in the research sample was twenty journals. There are eleven journals that discuss critical thinking. Of the eleven journals that have been criticized, critical thinking is a research journal that shows that critical thinking in children can increase and expand knowledge in children. Of the eleven journals, four of them discuss improving children's critical thinking through a scientific approach. The journal entitled increasing critical thinking skills through a scientific approach written by Yuniati, et al. (2019) discusses that learning activities with a scientific approach can foster children's thinking skills, because with this scientific approach children can directly participate in every activity to try and do it individually or in groups so that children can stimulate critical thinking, besides using this scientific approach children can find solutions and be able to solve any problems that arise during the activity. During the course of this scientific learning activity the children used the $5 \mathrm{M}$, namely
(Observing, Asking, Trying, Reasoning, and Communicating) indirectly by using the $5 \mathrm{M}$ children were developing their critical thinking.

Related to the findings above Misyana and Mayasari (2019) also discussed about increasing critical thinking skills through problem-solving science learning activities in group A children, in this research activity followed by group $A$ children whose interest in playing was very high, so it was decided to use scientific methods problem solving, with this problem-solving activity children can observe the problems they have experienced so that they can solve problems easily, and children can conclude their own conclusions from the problem-solving science game. From the science learning activities this problem solving becomes an alternative in the development of children's critical thinking skills which are influenced by indicators of children's critical thinking namely the ability to ask, observe, analyze,

The next finding is to discuss the effect of learning models and the ability to think critically on understanding of physical science written by Dewi et al. (2019), namely discussing that in this study researchers used two types of learning, namely the type of quantum learning activities and the contextual teaching and learning learning model. Quantum is believed that learning with this model can make children interested, challenging and fun for children, while contextual teaching and learning is learning activities that combine learning material with actual living conditions. Both learning models are child-centered learning models, but the quantum learning model is more enjoyable 
and fun for children. From the learning activities above, it can be seen if children who have the ability to think critically are children who can answer the questions that have been given, and there are even children who are able to understand the learning given. This shows that the ability of children to think critically is different. Of the two learning models in early childhood, learning using the quantum model is more critical than the contextual teaching and learning model.

Furthermore, research that also discusses increasing critical thinking skills in science learning through the group B children's play method written by Fadhila, et al (2019), which discusses playing methods in children's learning activities can improve critical thinking skills in children, because the play method can improve also the child's curiosity about new things. Not only to improve children's critical thinking skills, the play method also frees the child to communicate and also explore, so that the application of play methods in early childhood learning really helps children to add critical thinking skills.

Of the four journals above, both use a scientific approach to foster children's critical thinking skills, but the methods in presenting different learning are using quantum and contextual teaching and learning methods, using the play method, watching video shows about flying balloons and not. , and observing concrete objects. From the four types of methods used, it can be concluded that to improve children's thinking skills can use various methods that stimulate children's curiosity and always want to explore.
The next finding is discussing about increasing art appreciation in children and critical thinking based on an intervention visual literacy program written by Kim, et al. (2017) which discusses art education for early childhood where in this art education children can appreciate the results of a artwork and children are free to discuss, discuss and also reflect on their ideas and experiences. From the discussion that the children get about art they can exchange ideas with one another. So that children can appreciate art and then discuss and discuss indirectly children can improve critical thinking.

Of the twenty journals above also discussed about improving children's critical thinking by telling puzzle stories written by Muryanti and Herman (2016) who discussed that, storytelling is something that attracts attention to young children by telling stories can also implement an increase in critical thinking children, in this journal the child is asked to tell a story but beforehand the child is asked to arrange according to the order of the puzzle that has been provided, after the child can arrange the puzzle according to the order the child can tell according to the information they get from the arrangement of the puzzle, indirectly this game can build critical thinking of children.

Of the eleven journals that discuss critical thinking, there are also journals that discuss critical thinking skills tests (CTTC) for children aged 5-6 years written by Yarah and Aytar (2020) in this study discussing that critical thinking can be by children from an early age and can be developed over a lifetime. With children having critical thinking skills, 
children can easily solve a problem they are facing, evaluate, use information correctly, and can choose correct or incorrect information. To find out children's critical thinking skills and measure children's critical thinking skills, a children's critical thinking skills test was conducted using a variety of stories to be read. From the stories read, it can be seen whether the children are interested in the stories. pay attention to every sentence that is read or not. Of all the stories read at the end of the story, no conclusions are given, so as not to change the opinion the child has received. From the tests that have been given to the child, then the child is given questions about the story that has been read, by asking the child to make the right title for the story that has been read. has been read out, then whatever characters are in the story. Every answer that comes out of the child's mouth will be drawn by a graphic design, recorded, and recorded. From all the information obtained, it is then processed into a score obtained by the child. The purpose of the test is to determine and determine children's critical thinking skills. In order not to change the opinion that has been received by the child, from the test that has been given to the child, then the child is asked questions about the story that has been read, by asking the child to make the right title for the story that has been read, then what characters are in the story the. Every answer that comes out of the child's mouth will be drawn by a graphic design, recorded, and recorded. From all the information obtained, it is then processed into a score obtained by the child. The purpose of the test is to determine and determine children's critical thinking skills.
In order not to change the opinion that has been received by the child, from the test that has been given to the child, then the child is asked questions about the story that has been read, by asking the child to make the right title for the story that has been read, then what characters are in the story the. Every answer that comes out of the child's mouth will be drawn by a graphic design, recorded, and recorded. From all the information obtained, it is then processed into a score obtained by the child. The purpose of the test is to determine and determine children's critical thinking skills. then whatever characters are in the story. Every answer that comes out of the child's mouth will be drawn by a graphic design, recorded, and recorded. From all the information obtained, it is then processed into a score obtained by the child. The purpose of the test is to determine and determine children's critical thinking skills. then whatever characters are in the story. Every answer that comes out of the child's mouth will be drawn by a graphic design, recorded, and recorded. From all the information obtained, it is then processed into a score obtained by the child. The purpose of the test is to determine and determine children's critical thinking skills.

The next finding is to discuss the effectiveness of the philosophy curriculum on critical thinking skills of pre-school children written by Karadag and Demirtas (2018) in this study discussing that the effectiveness of philosophy in children can allow children to think critically with philosophical methods. In this method, children want to be able to form their interests and skills, even though children cannot learn philosophy, but at least children 
can do philosophy using this philosophical method. From learning using this philosophical method it can be seen that the achievements of children are better and have a high level of critical thinking, not only that using this philosophical method in children's education can have a positive impact on language skills,

Of the eleven journals that discuss critical thinking, there are also journals that discuss character values, critical thinking and early childhood psychomotor written by Hidayat and Nur (2018) in this study discussing where educational values are very important for early childhood in during the golden age, the values of education that can be obtained by children can come from teachers and parents at home. Mental, moral, critical thinking and psychomotor are needed and very important for early childhood during their growth and development. From the research results discussed, the environment is very important and influential in the development of character values, critical thinking and psychomotor in children.

The next finding discusses increasing critical thinking skills through environmentbased experimental methods written by Anggreani (2015), this finding discusses critical thinking in children who can build their own knowledge, not only that by thinking critically children can analyze and conclude the knowledge they can. Through the use of the experimental method, children can dive right in to find answers to every activity they do. By using the experimental method, children can also improve skills in terms of cognitive, critical thinking, and motoric aspects. In this research, the activities carried out are by mixing color experiments, floating-sinking experiments, dissolving-insoluble experiments, light-weight experiments, solid matter experiments into melting and magnetism experiments. Of all the activities that have been carried out can stimulate children to improve critical thinking skills, where children will understand the cause and effect, and also the answers of every activity they have done.

The last finding that discusses critical thinking is the construction of critical thinking through the introduction of the clock function and the concept of time in early childhood written byWardhani and Sadiyah (2018) who discuss the introduction of the function of the clock in early childhood is very important, namely in terms of familiarizing children with habits that must be done every day, such as school entry and school time, as well as prayer times. Time concept is an abstract concept where children need higher order thinking. The concept of time which is associated with the routine habits of children or also reading the numbers on the clock is an effort to increase critical thinking in children. In this study, children are also taught to understand the length or time of an activity, solve daily problems, also behave creatively and think critically.

The conclusion of eleven journals that discusses Christian thinking, namely using a variety of methods to achieve increased critical thinking in children. Of the various methods and methods used have their respective interests to attract attention to children to follow every step taken to improve critical thinking in children. Among them using puzzle games, role playing methods, scientific 
methods, experimental methods, introduction to the concept of hours, methods of play, of all the methods used, children can analyze, find out the cause and effect, find a way out of the problems they are doing in the activities or games that they do it by thinking critically or thinking broadly. It is the same as said by Zakiyah and Lestari (2019) which states that there are several aspects of critical thinking, namely interpretation, analysis, and explanation.

\section{Question and answer method}

Of the twenty sample journals, nine of them discussed the question and answer method. Two of them discuss language improvement using the question and answer method, the first finding is about improving language development through the question and answer method written by Pasanea, et al. (2015) in this study explaining that during the golden age of early childhood, it can develop. optimally if the method used is also correct. As when improving language development, researchers use question and answer methods to optimize language development in children. The question and answer method itself is a method in which two-way communication occurs, where teachers and children can communicate questions and answers well, By using this question and answer method, children are also freed to seek the knowledge they need. This study also uses a tool, namely using a flip chart, using a flip chart can help or facilitate optimization of learning and language development using the question and answer method. The flip chart media used during learning becomes interesting and fun, because the pictures shown attract children's attention and indirectly the children's curiosity increases and motivates children to ask questions and with learning like this motivates children to answer questions which was brought up by the teacher. If the child dares to ask and answer, an award will be given, namely applause from the teacher and class friends. This study also uses a tool, namely using a flip chart, using a flip chart can help or facilitate optimization of learning and language development using the question and answer method. The flip chart media used during learning becomes interesting and fun, because the pictures displayed attract children's attention and indirectly the children's curiosity increases and motivates children to ask questions and with learning like this motivates children to answer questions which was brought up by the teacher. If the child dares to ask and answer, an award will be given, namely applause from the teacher and classmates. This research also uses a tool, namely using a flip chart, using a flip chart can help or facilitate optimization of learning and language development using the question and answer method. Flip chart media used during learning becomes interesting and fun, because the pictures that are displayed attract the attention of children and indirectly the children's curiosity increases and motivates children to ask questions and with learning like this motivates children to answer questions which was brought up by the teacher. When children dare to ask and answer, they will be given an award, namely applause from the teacher and classmates. Using flip charts can help or facilitate optimizing language learning and development 
using the question and answer method. The flip chart media used during learning becomes interesting and fun, because the pictures displayed attract children's attention and indirectly the children's curiosity increases and motivates children to ask questions and with learning like this motivates children to answer questions which was raised by the teacher. If the child dares to ask and answer, an award will be given, namely applause from the teacher and class friends. Using flip charts can help or facilitate optimizing language learning and development using the question and answer method. The flip chart media used during learning becomes interesting and fun, because the pictures displayed attract children's attention and indirectly the children's curiosity increases and motivates children to ask questions and with learning like this motivates children to answer questions which was raised by the teacher. If the child dares to ask and answer, an award will be given, namely applause from the teacher and class friends. because the pictures displayed attract the attention of the child and indirectly the child's curiosity increases and motivates the child to ask questions and with learning like this motivates the child to answer the questions raised by the teacher. If the child dares to ask and answer, an award will be given, namely applause from the teacher and class friends. because the pictures displayed attract the attention of the child and indirectly the child's curiosity increases and motivates the child to ask questions and with learning like this motivates the child to answer the questions raised by the teacher. If the child dares to ask and answer, an award will be given, namely applause from the teacher and class friends.

Regarding the findings above, Muslimah, et al. (2018) also discussed improving children's language skills with the question and answer method, in this study discussing that language is a tool used to communicate with each other, language is also not only important for adults but early childhood. also requires a good understanding of language. The language used by early childhood is very much influenced by the people around them or their environment, and the most important thing is the language used by both parents. To develop language in early childhood requires appropriate methods, one of which is using the question and answer method. Using the question and answer method not only improves language development, but children freely increase their knowledge and broaden their curiosity. Because using this method can motivate children in terms of their desire to learn and curiosity by asking and answering what they understand. Therefore the importance of motivation from the teacher when children ask and answer can make children interested in learning and can improve language development by using the question and answer method.

From the two journals above that both use the question and answer method to improve children's language development, it can be concluded that language is very important for children, and one of the right methods to improve it is to use the question and answer method, where by using this method children can freely search. know, ask, 
and answer the knowledge they need and the knowledge they already understand. From one of the journals, a flip chart tool is also used to complete, attract children's attention and help when learning is being done.

Of the 9 journals that discuss the question and answer method, one of them also discusses developing the ability of early childhood in understanding rules using a combination of role playing methods and question and answer methods through traffic signs written by Wamaungu and Astuti (2018) in this study discussing that Understanding a rule from an early age is really needed by children, because by teaching children to obey every existing rule, the child is ready to jump into the environment. To implement a rule, learning media in the form of traffic signs are used, and develop it using a combination of role playing and question and answer methods. By using the role-playing method, the child immediately plunges into the character that has been determined and directly demonstrates, and it is hoped that the child can understand every traffic sign rules that have been provided, and use the question and answer method to make the atmosphere more interesting because there will be questions and answers for every child's curiosity. The question and answer method itself facilitates children to get the right information from the teacher who guides them during the activity. So that the learning process becomes more optimal and fun, children indirectly develop their social emotions through understanding each traffic sign by using role playing and question and answer methods. The question and answer method itself facilitates children to get the right information from the teacher who guides them during the activity. So that the learning process becomes more optimal and fun, children indirectly develop their social emotions through understanding each traffic sign by using role playing and question and answer methods. The question and answer method itself facilitates children to get the right information from the teacher who guides them during the activity. So that the learning process becomes more optimal and fun, children indirectly develop their social emotions through understanding each traffic sign by using role playing and question and answer methods.

The next finding is to discuss efforts to improve speaking skills through the question and answer method written by Munasih and Nurjaman (2017) in this journal, it is explained that early childhood development is very rapid and very good, if the stimulus is given right so that it develops optimally. One of the methods used to optimize children's speaking development is by using the question and answer method, because with this method children can easily interact with questions and answers and express the findings they get, the teacher can also ask questions to answer the questions given by the child. By using this method the child will feel happy because the method used is interesting. Talking is very important for children because children can communicate well,

In addition to improving speaking skills, the question and answer method can also improve children's skills in understanding good personalities (honest, helpful) using the story 
telling method and the examples and non examples method written by Putri and Novitawati (2017). Early education is very important, especially the education obtained from both parents and teachers at school, through the introduction of social emotional to children which starts from seeing the treatment of both parents and teachers who indirectly show good things around children to make children imitate and apply so that he becomes an honest person who likes to help and has a high sense of empathy. To further optimize the improvement of children's noble behavior, storytelling and question and answer methods are also used plus examples and nonexamples methods. Using the storytelling method can attract children's attention from the stories presented and also has messages that can help children improve their social emotional, question and answer method that provides facilities for children to communicate in two ways with the teacher. The examples and non examples methods presented by the teacher are in the form of attractive pictures so that children can see and optimize the development of noble behavior and apply all the lessons that have been given by the teacher. Using the storytelling method can attract children's attention from the stories presented and also has messages that can help children improve their social emotional, question and answer method that provides facilities for children to communicate in two ways with the teacher. The examples and non examples methods presented by the teacher are in the form of attractive pictures so that children can see and optimize the development of noble behavior and apply all the lessons that have been given by the teacher. Using the storytelling method can attract children's attention from the stories presented and also has messages that can help children improve their social emotional, question and answer method that provides facilities for children to communicate in two ways with the teacher. Examples and non examples methods presented by the teacher in the form of interesting pictures so that children can see and optimize the development of noble behavior and apply all the learning that has been given by the teacher.

The next finding is to discuss the effect of the question and answer method on children's learning motivation written by Ashadi (2018). The question and answer method is a method that can motivate children to explore curiosity, and explore the knowledge around them, indirectly the child has questions that want to be asked. By using this method, children can listen to every explanation from the teacher, ask each other and answer each other. Activities that are made fun and interesting for children using the question and answer method can motivate children to learn and find out the knowledge around them.

Besides being able to influence learning motivation, the question and answer method can also improve the language skills of recognizing vowels in children written by Setyowati (2018). In this study discussed that during the golden age of development in children develop optimally, a lot of things they can follow and learn from the surrounding environment. With children easily 
understanding the things around them, learning becomes easier. One of them is recognizing vowels in children. Through the question and answer method, the teacher can give questions and children can answer and vice versa. Using this method aims to monitor children's attention so that it is always focused, and from using this question and answer method it can improve children's ability to recognize vowels.

The next finding is to discuss the effect of puzzle games and discussion methods on early childhood knowledge and attitudes about sexuality written by Muflihah et al (2019). Early childhood is where golden times cannot be repeated, so parents must always monitor their every growth and development. In the golden age, children could easily absorb important and useful information for children, including knowledge about sexuality. Knowledge about sexuality is often considered taboo, but this knowledge is very important to teach children, which parts of the body can or should not be seen by others or touched. So that puzzle games and discussion methods are used which can make children interested and want to pay attention to every explanation given through puzzle games. in this way the child can understand the body's functions, which parts can and should not be touched or seen by others. So that children can increase knowledge about sexuality.

The latest findings discussing the question and answer method, namely the title of improving children's communication skills through the question and answer method written by Muraeni and Mursanib (2019). In this study, it is discussed that early childhood is able to absorb information well, so that many activities in early childhood learning are interesting and fun so that children easily remember the knowledge gained. In this study children are expected to be able to communicate well through the question and answer method, which question and answer method is a two-way communication method and is effectively used when learning. Using interesting and fun games such as randomly pointing letters,

From the nine journals that use the question and answer method, it can be concluded that using the question and answer method can develop children's language, speaking skills, social emotional, learning motivation, and good communication. From all of the above, it allows children and teachers to establish good two-way communication, to optimize learning, also not forget to insert fun and interesting activities for children so that children feel happy and interested in activities as well as every communication that exists. As stated by Sukadinata (2011) the question and answer method is teaching which allows direct and two-way communication.

\section{CONCLUSION}

The conclusion from eleven journals that discuss critical thinking, namely using various methods to achieve increased critical thinking in children. Of the various methods and methods used have their respective interests to attract attention to children to follow every step taken to improve critical thinking in children. Among them using puzzle games, role playing methods, scientific methods, experimental methods, introduction 
to the concept of hours, methods of play, of all the methods used, children can analyze, find out the cause and effect, find a way out of the problems they are doing in the activities or games that they do it by thinking critically or thinking broadly. It can be concluded that the nine journals that use the question and answer method can develop children's language, speaking skills, social emotional, learning motivation, and good communication. From all of the above, it allows children and teachers to establish good two-way communication, to optimize learning, also not forget to insert fun and interesting activities for children so that children feel happy and interested in activities as well as every communication that exists. With learning that is fun and interesting for children, the development of the children will increase optimally in the present and in the future. From all of the above, it allows children and teachers to establish good two-way communication, to optimize learning, also not forget to insert fun and interesting activities for children so that children feel happy and interested in activities as well as every communication that exists. With learning that is fun and interesting for children, the development of the children will increase optimally in the present and in the future. From all of the above, it allows children and teachers to establish good two-way communication, to optimize learning, also not forget to insert fun and interesting activities for children so that children feel happy and interested in activities as well as every communication that exists. With learning that is fun and interesting for children, the development of the children will increase optimally at present and in the future.

\section{REFERENCES}

Ashadi, F., \& PGRI Jember, I. (2018). Education Journal : Journal Education Research and Development PENGARUH METODE TANYA JAWAB TERHADAP MOTIVASI BELAJAR ANAK USIA DINI DI TK KANZUL MAKARIM GLENMORE BANYUWANGI. Education Journal: Journal Education Research and Development, 2(2), 46-52. https://jurnal.ikipjember.ac.id/index.php /ej/article/view/112

Depdiknas.2003.Undang-undang RI No.20 Tahun 2003.Tentang sistem pendidikan nasional.

Dewi, A. C., Hapidin, H., \& Akbar, Z. (2019). Pengaruh Model Pembelajaran dan Kemampuan Berpikir Kritis terhadap Pemahaman Sains Fisik. Jurnal Obsesi : Jurnal Pendidikan Anak Usia Dini, 3(1), 18. https://doi.org/10.31004/obsesi.v3i1.13 6

Fadlila, N., Palupi, W., \& Hafidah, R. (2019). Peningkatan Kemampuan Berpikit Kritis dalam Pembelajaran Sains Melalui Metode Bermain Anak Kelompok B TK Aisyiyah Punggawan Taun 2016/2017. Jurnal Kumara Cendekia, 7(1). https://jurnal.uns.ac.id/kumara

Herawati, M. M. (2019). MENINGKATKAN KEMAMPUAN ANAK BERKOMUNIKASI 
MELALUI METODE TANYA JAWAB DI KELOMPOK B TK ANDINE PALUPI. 5(1), 19. file:///H:/SKRIPSI NEW/JURNAL NASIONAL/METODE TANYA JAWAB/JURNAL MTJ 7 (2019) \%5E.pdf

Hidayat, S., \& Nur, L. (2018). Nilai Karakter, Berpikir Kritis Dan Psikomotorik Anak Usia Dini. Jiv, 13(1), 29-35. https://doi.org/10.21009/jiv.1301.4

Hidayat, S., \& Nur, L. (2017). Critical Thinking Skill. Konsep dan indikator penilaian. Jurnal taman cendekia.

Indrijati Herdina. 2016. Psikologi perkembangan dan pendidikan anak usia dini. PT Fajar Intrerpratama Mandiri.

Kim, K. J., Wee, S. J., Han, M. K., Sohn, J. H., \& Hitchens, C. W. (2017). Enhancing children's art appreciation and critical thinking through a visual literacy-based art intervention programme. International Journal of Education Through Art, 13(3), 317-332. https://doi.org/10.1386/eta.13.3.317_1

Karadağ, F., \& Demirtaş, V. Y. (2018). The effectiveness of the philosophy with children curriculum on critical thinking skills of pre-school children. Egitim ve Bilim, 43(195), 19-40. https://doi.org/10.15390/EB.2018.7268

Kurniati, E., Mirawati, Rudiyanto, Fitriani, A. D., Rengganis, I., \& Justicia, R. (2019). Jurnal Pendidikan: Early Childhood. Jurnal Pendidikan: Early Childhood, 3(2), 1-6.
https://journal.umtas.ac.id/index.php/EA RLYCHILDHOOD/article/view/283

Mansur. 2009. Pendidikan Anak Usia Dini dalam Islam. Yogyakarta: Pustaka Pelajar.

Mengenai, T., Studi, S., \& Tk, D. I. (2019). Pengaruh Permainan Puzzle Dan Metode Diskusi Terhadap Pengetahuan Dan Sikap Anak Usia Dini (5-6 Tahun) Mengenai Seksualitas (Studi Di Tk Kelurahan Bugangan, Semarang Timur, Kota Semarang). Jurnal Kesehatan Masyarakat (e-Journal), 7(1), 483-490. http://ejournal3.undip.ac.id/index.php/j $\mathrm{km}$

Muhibbin Syah. 2010. Psikologi Pendidikan dengan Pendekatan Baru. Bandung: PT Remaja Rosdakarya

Misyana, I. M. (2019). Jurnal Pendidikan : Early Childhood MELALUI BERMAIN SAINS PADA ANAK TK A DI LABORATORIUM PAUD YASMIN KABUPATEN JEMBER. Jurnal Pendidikan : Early Childhood, 2(2), 1-7. https://doi.org/2579-7190

Munasih, A. \&, \& Nurjaman, I. (2017). Upaya Meningkatkan Kemampuan Berbicara Melalui Metode Tanya Jawab Pada Anak Usia 4 - 5 Tahun. Jurnal Program Studi Pendidikan Anak Usia Dini, 6(1), 1-15. http://jurnal.umt.ac.id/index.php/ceria/a rticle/view/553

Muryanti, E., \& Herman, Y. (2017). Building Children's Critical Thinking by Puzzle Story Telling. Atlantis Press, 58, 147-151. 
https://doi.org/10.2991/icece16.2017.25

Muslimah, A., Alim, M. L., \& Ayu, C. (2018). Meningkatkan Kemampuan Berbahasa.

Pasanea, M. R. H., Sujana, I. W., \& Negara, I. G. A. O. (2015). Tanya Jawab Berbantuan Media Flip Chart Pada Anak Kelompok B1 Tk Ikal Widya Kumara. PG-PAUD Universitas Pendidikan Ganesha, 3(1), 111.

https://doi.org/http://dx.doi.org/10.238 87/paud.v3i1.5001

Putri, O. M., \& Novitawati. (2017). Mengembangkan Kemampuan Anak Usia Dini dalam Memahami Perilaku Mulia (Jujur, Penolong) Menggunakan Kombinasi Metode Bercerita, Metode Tanya Jawab dan Model Examples Non Examples. J-PPras, 1(1), 29-34. https://rumahjurnal.net/index.php/JPP/a rticle/view/200/0

Sudaryono. 2016. Metode Penelitian Pendidikan. Jakarta: Kencana.

Sugiyono. 2016. Metode Penelitian Pendidikan. Bandung: Alfabeta CV

Sukadinata Nana Syaodih. 2011. Metode Penelitian Pendidikan. Bandung: PT Remaja Rosdakarya

Suyadi dan Ulfah. 2015. Konsep Dasar PAUD. Bandung: PT Remaja
Tindakan, P., \& Mentari, B. P. (2015). LINGKUNGAN PAUD PPs Universitas Negeri Jakarta kritis satu. Jurnal Pendidikan Anak Usia Dini, 9(2), 343-360. https://doi.org/https://doi.org/10.21009 /JPUD.092 DOI: https://doi.org/10.21009/JPUD.092

Tozduman Yaralı, K., \& Güngör Aytar, F. A. (2020). The critical thinking skills test for 5-6 year-old children (CTTC): A study of validity and reliability. Elementary Education Online, 19(3), 1439-1449. https://doi.org/10.17051/ilkonline.2020. 730757

Wamaungu, J. A., \& Astuti, S. W. (2017). Developing Early Childhood Ability in Understanding Rules Using Combination of Role-Playing Model and QuestionAnswer Method Through Medium of Traffic Signs. Journal of K6, Education and Management, 01(2), 11-18. http://dev.jk6em.org/index.php/jkemorg/article/vie $\mathrm{w} / 8$

Wardhani, E. K., \& Setyowati, S. (2015). Melalui Metode Tanya Jawab Pada Anak. PAUD Teratai, 4(3), https://jurnalmahasiswa.unesa.ac.id/ind ex.php/paud-teratai/article/view/13339

Yunita, H., Meilanie, S. M., \& Fahrurrozi, F. (2019). Meningkatkan Kemampuan Berpikir Kritis melalui Pendekatan Saintifik. Jurnal Obsesi : Jurnal Pendidikan Anak Usia Dini, 3(2), 425. https://doi.org/10.31004/obsesi.v3i2.228 